\title{
A eXPeriÊnCIA MÁGICA de Henri MichauX'
}

\section{Maurice Blanchot}

Da obra tão diversa, tão rara e tão importante de Henri Michaux, é possível reter aspectos bastante diferentes. Mas ele acaba de publicar, quase ao mesmo tempo, uma nova coletânea, com o nome de Exorcismos, ${ }^{*}$ e uma seleção de páginas escolhidas de suas obras anteriores, que, por seu título e sua direção, designa o aspecto de si mesmo de que o autor quer nos fazer tomar consciência. O Espaço do dentro* é também uma coletânea de exorcismos. Trata-se de uma sequência de quadros que evoca uma experiência mágica. Pinturas, contos, poemas, encantações, essa experiência ali se exprime por meios literários extraordinariamente eficazes, mas que não buscam um fim literário.

A palavra magia é frequente na obra de Henri Michaux. Ele chamou uma de suas coletâneas de No país da magia, e várias de suas páginas também levam este nome. Mas se toda uma parte de sua obra aparece como o esforço de uma consciência mágica, como o engendramento de uma realidade mágica, é preciso imediatamente notar que o termo por ele empregado não tem o sentido vago, gasto, com o qual o uso habitualmente se contenta. Magia é coisa diferente de um poder de encantamento, e póe à disposição do homem recursos extraordinários.

"Escrevo como posso [diz Michaux] a primeira vez aconteceu depois de uma aposta, ou melhor, de uma fúria. Fiquei muito surpreso com o resultado da explosão, que foi chamado de poema. Isso se repetiu. Ainda não me habituei. Escrevo com arrebatamento e para mim..." Uma grande parte de sua obra é marcada por essa presença de uma emoção violenta. A fúria lhe dá sua forma de perpétua agressão, de luta ardilosa e impulsiva, de reação de defesa, contra um objeto ele próprio dotado de malvadez, agressivo, desarrazoadamente cruel ("Na verdade, anota ele ao descrever os Movimentos do ser interior, aquele que não conhece a fúria nada sabe. Não conhece o imediato"). O que a fúria construiu, a angústia ou o medo destrói. A construção é vertiginosa, instantânea, uma espécie de catarata, um acesso tão poderoso que num momento triunfa sobre a nulidade de seus próprios meios. (Um dos temas essenciais

\footnotetext{
${ }^{1} 17$ de agosto de 1944
}

*(Exorcismes. Paris: RobertGodet, 1943.)

" (L'Espace du dedans. Paris: Gallimard, 1944.)

* (Au pays de la magie. Paris: Gallimard, 1941.)

(Mouvements de l'être intérieur. Paris: Gallimard, 1938.) 
de Michaux é o tema do construtor. O construtor parece absurdo porque constrói com qualquer coisa; mas ele pode, justamente, construir com qualquer coisa: é senhor de um mundo que se ri da sabedoria expediente, é capaz daquilo que sente: "Construirei para vocês uma cidade com trapos! Construirei para vocês sem projeto e sem cimento um edifício que vocês não destruirão...") Mas a angústia desfaz lentamente, pacientemente, arruína por antecipação, anula, antes que ele venha a existir, o edifício da espontaneidade e da tempestade. Ela é a noite dos estorvos, projeta indefinidamente a desordem e o desequilíbrio. Tudo está sempre por ser refeito, tudo desaparece, e a própria morte, como na visão hindu, não passa da promessa de um recomeço sem termo. ("Neste universo, há poucos sorrisos. Quem nele se move faz uma infinidade de encontros que o ferem. No entanto, não se morre nele. Se se morre, tudo recomeça.")

É por ser o produto direto da emoção que o mundo de Michaux é um mundo mágico. $\mathrm{Na}$ emoção, tentamos abrir para nós um caminho para um mundo que não seja mais regulado por relações razoáveis e inteiramente determinadas, mas pela magia. A fúria, por exemplo, é um comportamento mágico que tende a abater com um só golpe um ser ou um objeto que não temos tempo de combater realmente. $\mathrm{O}$ mundo real é difícil demais, lento demais. A fúria não quer esperar, não tem a paciência de seguir as vias sinuosas que a ela se oferecem para uma ação verdadeira. Ela apagará, portanto, todos os dados práticos, e substituirá a ação concreta da vingança por uma ação simbólica, uma ação mágica por gestos, ameaças, palavras nas quais, fora do tempo, ela se realizará em todo o furor de seu desejo. Assim começam para o homem novas relações com o mundo. Mas é apenas um começo. Pois assim que as coisas perdem sua estrutura racional e definida, elas se apoderam da consciência que as suscitou e forçam-na a uma catividade extenuante. A fúria, para se desembaraçar do mundo odioso que a afronta, se precipita num mundo de embaraços que ela jamais consegue superar. Terríveis são os objetos de Michaux, de uma potência de agressão sem igual, de uma ferocidade maldosa inesgotável. Pois ele próprio, por sua fúria, os constituiu em um mundo de hostilidade, em uma muralha, sempre a ruir e sempre a renascer, de ferocidade e de malícia. E não se trata de uma projeção imaginária. $\mathrm{O}$ mundo da emoção é exatamente assim, retraindo-se sobre a consciência, engolindo-a pouco a pouco, encerrando-a em si mesma, dando-lhe 
a certeza de que ela está para sempre cativa e que, assim prisioneira, só pode justamente recorrer, para defender-se, a meios encantatórios, a meios que a libertam momentaneamente mas que ao mesmo tempo a afundam ainda mais, fazendo com que fique intimamente solidária do mundo mágico de que ela pretende alforriarse ao tornar-se cada vez mais magia ("O ser interior combate continuamente larvas gesticuladoras. Ele se vê subitamente esvaziado delas como de um grito, como de detritos levados por um furacão repentino. Mas a invasão logo recomeça por baixo...”)

O mundo de Michaux é a um só tempo espontaneidade imprevisível e inércia infinita. Espontaneidade e passividade são as duas características do mundo mágico. A consciência perdeu-se entre as coisas. Ela própria tornou-se uma coisa. Não tem mais limites nem formas. Tende ainda a uma certa finalidade, mas realiza-a por meios absolutos. Ao mesmo tempo, tudo é possível: é a ilusão do ser interior que realiza tudo o que imagina - e nada é possível pois, tomado na espessura da matéria, o espírito nada mais é senão paciência petrificada, indiferença ao abismo, massa viscosa que não cresce mais. A objetividade tão estranha de Um certo Plume, de Viagem à grande garabagne, de No país da magia exprime este trágico aspecto da consciência cuja intimidade, em vez de ser vivida e percebida de dentro, é contemplada de fora, vive em um mundo aberto, não é nada além de um espetáculo sem referência. Há em todas essas obras um esforço extraordinário - e um dos mais significativos desse tempo - para exprimir o homem pela ausência do homem, para descrever o mundo da realidade humana criando um mundo em que o homem não pode mais reconhecer-se, imaginando um ponto de vista do homem absolutamente estrangeiro ao homem. Está aí também o sonho angustiante da consciência mágica. Ela quer sair de si mesma, e não pode sair a não ser ao tornar para si mesma presente um mundo em que ela sempre se encontra. Ela tende a ultrapassar-se, e ultrapassar-se é para ela espalhar-se por toda parte, diluir-se em todas as coisas, estar até mesmo onde não está.

Se as intervenções de Henri Michaux nos parecem tão próximas e interessam nossa sorte, mesmo quando nada de nós está aparentemente envolvido, é primeiramente porque simbolizam esta condição geral de nosso destino que só pode encontrar um sentido por meio do esforço para escapar desse sentido e até mesmo de todo sentido possível - de maneira que a gratuidade de suas fábulas e de sua linguagem é o que mais nos importa. Porém, ao mes-
" (Un certain Plume. Paris: Gallimard, 1938.)

- Voyage en Grande Garabagne. Paris: Gallimard, 1936.) 
- (Mes propriétés. Paris: Gallimard, 1929.)

- (La Nuit remue. Paris: Gallimard, 1935.)

- (Lointain intérieur. Paris: Gallimard, 1938.) mo tempo, essa gratuidade, essa objetividade sem ressonância, essa placidez surda e cega faz parte de um movimento que, em sua outra extremidade, é potência de fúria e tempestade, ansiedade e desespero, emoção infinita. Não há obra contemporânea em que a angústia e o fracasso humanos tenham encontrado uma expressão a um só tempo mais reservada e mais violenta, uma voz mais altiva e mais trágica. Quem não guardaria a lembrança de Minhas propriedades, ${ }^{*}$ A noite se move, ${ }^{*}$ Longinquo interior, ${ }^{*}$ Um certo Plu$m e$, em que se fazem ouvir os lamentos graves e solenes de poemas como "Canto de morte"?...

A fortuna mais uma vez, a fortuna com língua de óleo, tendo lavado minhas feridas, a fortuna como um cabelo que pegamos e que trançaríamos aos nossos, tendo-me pego e unido indissoluvelmente a ela, de repente quando eu já saboreava a alegria, de repente a Morte veio e disse: "É hora. Venha." A Morte para todo o sempre a Morte agora.

Tradução de Marcelo Jacques de Moraes (UFRJ) 